\title{
Microscopy of Physcomitrella patens sperm cells
}

\author{
Nelly A. Horst ${ }^{1}$ and Ralf Reski ${ }^{1,2^{*}}$
}

\begin{abstract}
Background: Archegoniates (bryophytes, ferns and gymnosperms), such as the moss Physcomitrella patens, possess freely motile sperm cells (spermatozoids) which reach the egg cell via surface water. Although these motile flagellated sperm cells are a traditional botanical subject, they have not been thoroughly analysed in the flagship non-seed plant model species P. patens. Protocols are required to determine the behaviour of wild type sperms as a prerequisite for future research such as the characterization of mutants or factors that influence sperm number, morphology, viability and motility.

Results: Here, we present protocols for the observation of fixed, as well as live sperms utilizing a standard microscope at intermediate magnifications. Fixed samples can be used for the fast assessment of sperm number and morphology. To determine functionality, the observation of live sperms is required. Protocols for determining both sperm motility and viability are provided, allowing both parameters to be distinguished.

Conclusions: These step-by-step protocols are particularly useful for researchers so far not familiar with the analysis of motile gametes and are meant to aid the establishment and improvement of these analyses in order to stimulate research on spermatogenesis in the moss model species $P$. patens.
\end{abstract}

Keywords: Development, Land plant motile sperms, Moss, Physcomitrella patens

\section{Background}

Physcomitrella patens is the only non-seed land plant selected as a flagship genome by the Joint Genome Institute [1]. As an early-diverging land plant it has proven invaluable for the elucidation of the origin and evolution of developmental pathways during the conquest of land by plants [2-7]. The change from an aquatic to a terrestrial habitat required adaptions such as protection against desiccation [8]. Notably, archegoniate plants, such as the bryophytes, possess freely motile sperms that require surface water for fertilization.

The use of $P$. patens as a model organism requires methods and documentation of all life stages. The development and morphology of most gametophytic and sporophytic life stages is well-described, e.g. [9-13], providing the basis for the phenotypic analysis of mutants or

\footnotetext{
*Correspondence: ralf.reski@biologie.uni-freiburg.de

1 Plant Biotechnology, Faculty of Biology, University of Freiburg,

Schaenzlestr. 1, 79104 Freiburg, Germany

Full list of author information is available at the end of the article
}

in response to treatments. The notable exception is the analysis of the biflagellated spermatozoids, which was rarely addressed in P. patens research.

Bryophyte sperms are a traditional botanical subject $[14,15]$ and their ultrastructure has been extensively analysed [16-18]. While the light-microscopic analysis of the sperms is documented in many moss species, e.g. [19-24], and has become a recent focus in the liverwort Marchantia polymorpha $[25,26]$, the methodology is not established for $P$. patens. We assume the lack of detailed protocols is the major obstacle preventing research on $P$. patens sperms and discuss possible reasons so far hindering the establishment of suitable protocols.

At decreased temperatures and short day conditions [27] P. patens epidermis cells at and near the apex of the leafy gametophore reprogram into gametangia stem cells which give rise to the antheridia (Fig. 1) and later the archegonia [12]. The development of $P$. patens gametangia is described in [12]. Briefly, antheridia are multicellular structures with the inner cells developing into the spermatozoids (Fig. 2a, 


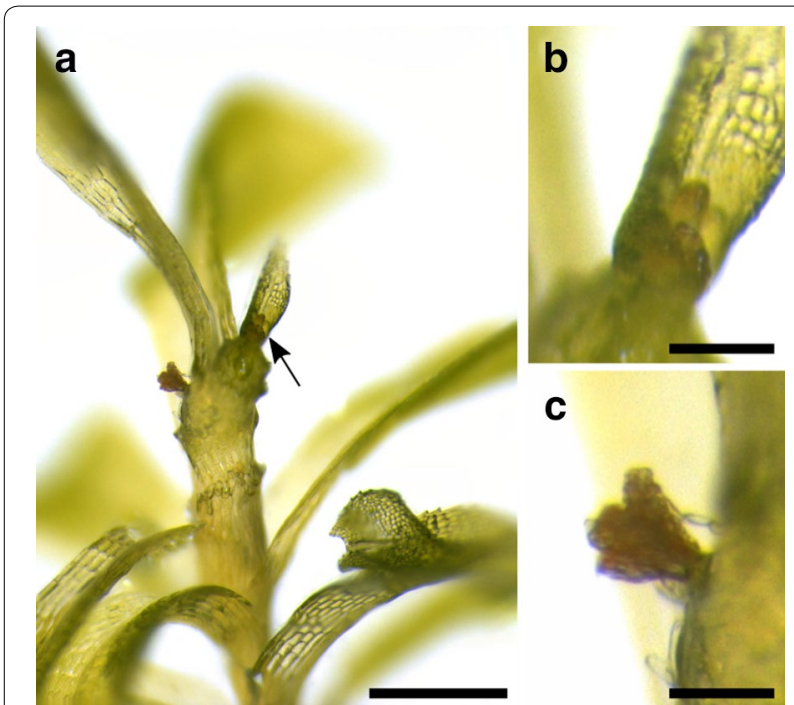

Fig. 1 Clusters of antheridia on a Physcomitrella gametophore (some leaves were removed). a A cluster of open, empty antheridia on the stem close to the apex and a cluster of closed antheridia at the apex which is suitable for the observation of sperms (arrow). b, c Magnification of the clusters of closed (b) and open (c) antheridia. Scale bars $500 \mu \mathrm{m}$ in $\mathbf{a} ; 50 \mu \mathrm{m}$ in $\mathbf{b}$ and $\mathbf{c}$

b). At maturity, an antheridium is an urn-shaped structure holding the sperms closed by an apical cap cell (Fig. 2c, d). The contents in the chamber of ripe antheridia are under pressure and contents of the apical cap cell become degraded, the cell becomes metastable [21]. Upon disturbance the apical cell bursts releasing the sperms (Fig. 2e$\mathrm{h}$ ). The sperm mass is embedded in a hydrophobic liquid/ matrix allowing a passive spread of a liquid layer on the water surface [22]. Requiring surface water, they reach the archegonium and fertilize the egg cell within.

\section{Protocols}

1. Induction of gametangia

- Prepare 9-cm vented petri dishes with about $45 \mathrm{ml}$ Knop mineral medium $250 \mathrm{mg} / \mathrm{L} \mathrm{KH}_{2} \mathrm{PO}_{4}$, $250 \mathrm{mg} / \mathrm{L} \mathrm{KCl}, 250 \mathrm{mg} / \mathrm{L} \mathrm{MgSO}_{4}, 1000 \mathrm{mg} / \mathrm{L}$ $\mathrm{Ca}\left(\mathrm{NO}_{3}\right)_{2}, 12.5 \mathrm{mg} / \mathrm{L} \mathrm{FeSO}_{4}$ [28], supplemented with microelements $\left(50 \mu \mathrm{M} \quad \mathrm{H}_{3} \mathrm{BO}_{3}, \quad 50 \mu \mathrm{M}\right.$ $\mathrm{MnSO}_{4} \times \mathrm{H}_{2} \mathrm{O}, 15 \mu \mathrm{M} \mathrm{ZnSO}_{4} \times 7 \mathrm{H}_{2} \mathrm{O}, 2.5 \mu \mathrm{M} \mathrm{KI}$, $0.5 \mu \mathrm{M} \mathrm{Na}_{2} \mathrm{MoO}_{4} \times 2 \mathrm{H}_{2} \mathrm{O}, 0.05 \mu \mathrm{M} \mathrm{CuSO}_{4} \times 5$ $\mathrm{H}_{2} \mathrm{O}, 0.05 \mu \mathrm{M} \mathrm{CoCl}_{2} \times 6 \mathrm{H}_{2} \mathrm{O}$ ) [29]. Adjust $\mathrm{pH}$ to 5.8 with $\mathrm{KOH}$. A protocol is provided in [30].

- Distribute up to twelve individual gametophores on a 9-cm petri dish. Entire gametophores are picked with flame-sterilized forceps (about $100 \mathrm{~mm}$ length) with fine serrated jaw (e.g. No. 10, Bochem Instrumente $\mathrm{GmbH}$, Weilburg, Germany). For best growth pick gametophores from plants that have been cultivated on Knop medium as specified above for 4-6 weeks.

- Seal 7/8 of the petri dish with Parafilm $\mathrm{M}^{\circledR}$ (Bemis Company, Inc., Neenah, WI, USA), and cover the remaining gap with Micropore ${ }^{\mathrm{TM}}$ Surgical Tape $\left(3 \mathrm{M}^{\mathrm{TM}}\right.$, Minnesota, USA). The gas exchange improves gametophore development.

- Cultivate the plants for at least five weeks in a growth cabinet or climate chamber at $22{ }^{\circ} \mathrm{C}$, under a 16:8 h light:dark photoperiod with a light intensity of $50-70 \mu \mathrm{mol} \mathrm{m}^{-2} \mathrm{~s}^{-1}$ [31].

- Critical step Prior to transferring the plates to gametangia-inductive conditions the plants need to be well-developed, i.e. gametophores should have a length of about $5 \mathrm{~mm}$. The necessary pre-cultivation time is variable, depending for example on the starting material and may need to be increased for mutants with impaired gametophore development. Bigger gametophores develop gametangia faster.

- Transfer the plates to gametangia-inductive conditions, i.e. $15{ }^{\circ} \mathrm{C}, 8: 16 \mathrm{~h}$ photoperiod with a light intensity of $20 \mu \mathrm{mol} \mathrm{m}^{-2} \mathrm{~s}^{-1}$ [27].

- Start checking for antheridia under a dissecting microscope after two weeks, clusters of antheridia of a light brown colour develop on the apex and on apical parts of the stem (Fig. 1).

- Note When no sporophytes develop, new antheridia keep developing leading to big clusters of antheridia. Though it may appear advantageous to have many antheridia to analyse, these clusters are composed mainly of dead antheridia containing non-viable sperm. Young clusters of antheridia as pictured in Fig. 1b should be selected for analysis.

2. Fixed samples for assessment of sperm number, sperm shape, and sperms within antheridia

- Place entire gametophores into the fixative $(50 \% \mathrm{v} / \mathrm{v}$ ethanol, $3.7 \% \mathrm{v} / \mathrm{v}$ formaldehyde, $5 \% \mathrm{v} / \mathrm{v}$ acetic acid) in a $1.5-\mathrm{ml}$ reaction tube for $30 \mathrm{~min}$. The volume of fixative should be at least $10 \times$ the sample volume. Remove the fixative by pipetting and replace it with water.

- Under a dissecting microscope, place a drop of water on a polylysine-coated slide (e.g. Poly-Prep Slides, Sigma-Aldrich, USA). Hold a gametophore with one pair of forceps and using another pair of forceps, brush the antheridia into the water and distribute them onto the slide.

- Let the slides dry on the benchtop overnight. The apical cells of some antheridia will rupture, releasing the sperms. 


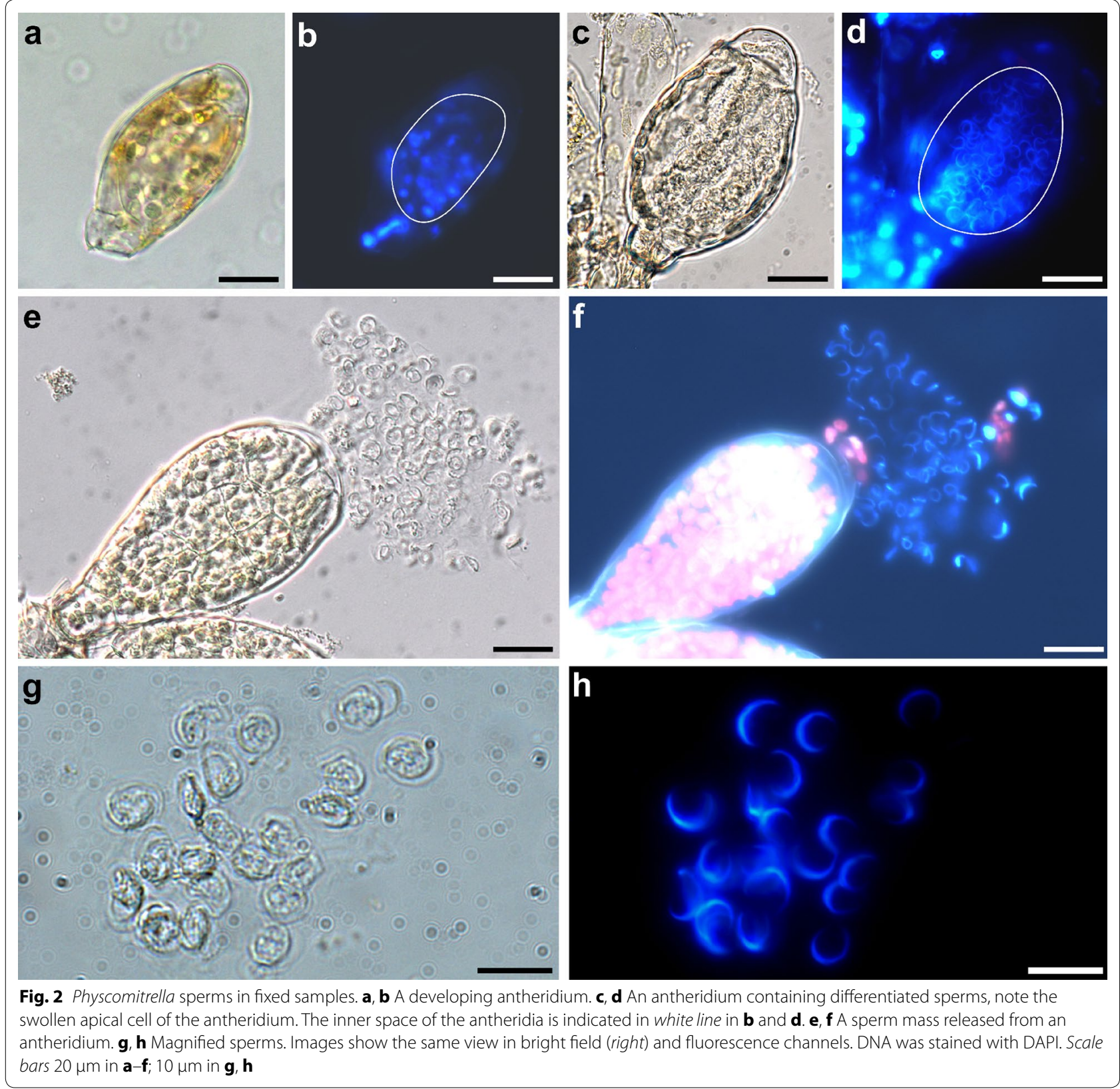

- Place a drop of phosphate-buffered saline containing $1 \mathrm{mg} / \mathrm{L}$ DAPI (4',6-diamidin-2'-phenylindole dihydrochloride, Sigma-Aldrich) on the sample and place a coverslip on top. The rehydrated samples, including the released sperms, will stay attached to the polylysine-coated slides.

- Observe developmental stages of maturing sperm within antheridia and released sperms (Fig. 2). At the beginning of spermatogenesis (Fig. 2a, b) the nuclei are spherical (as shown after staining with DAPI in Fig. 2b), mature spermatozoids (Fig. 2c-h) have a coiled nucleus.
- Mark all visible sperms to approximate their number (Fig. 3). Adequate selection of the sample and analysing different focal planes of the same antheridium will improve the accuracy of the result.

3. Observation of live cells for sperm motility

- Critical step Mechanical stimulus causes the apical cell of the antheridium to burst, releasing the sperms. To ensure the antheridia are intact they need to be undisturbed prior to observation. For this, attach the bottom of the closed petri dish with 

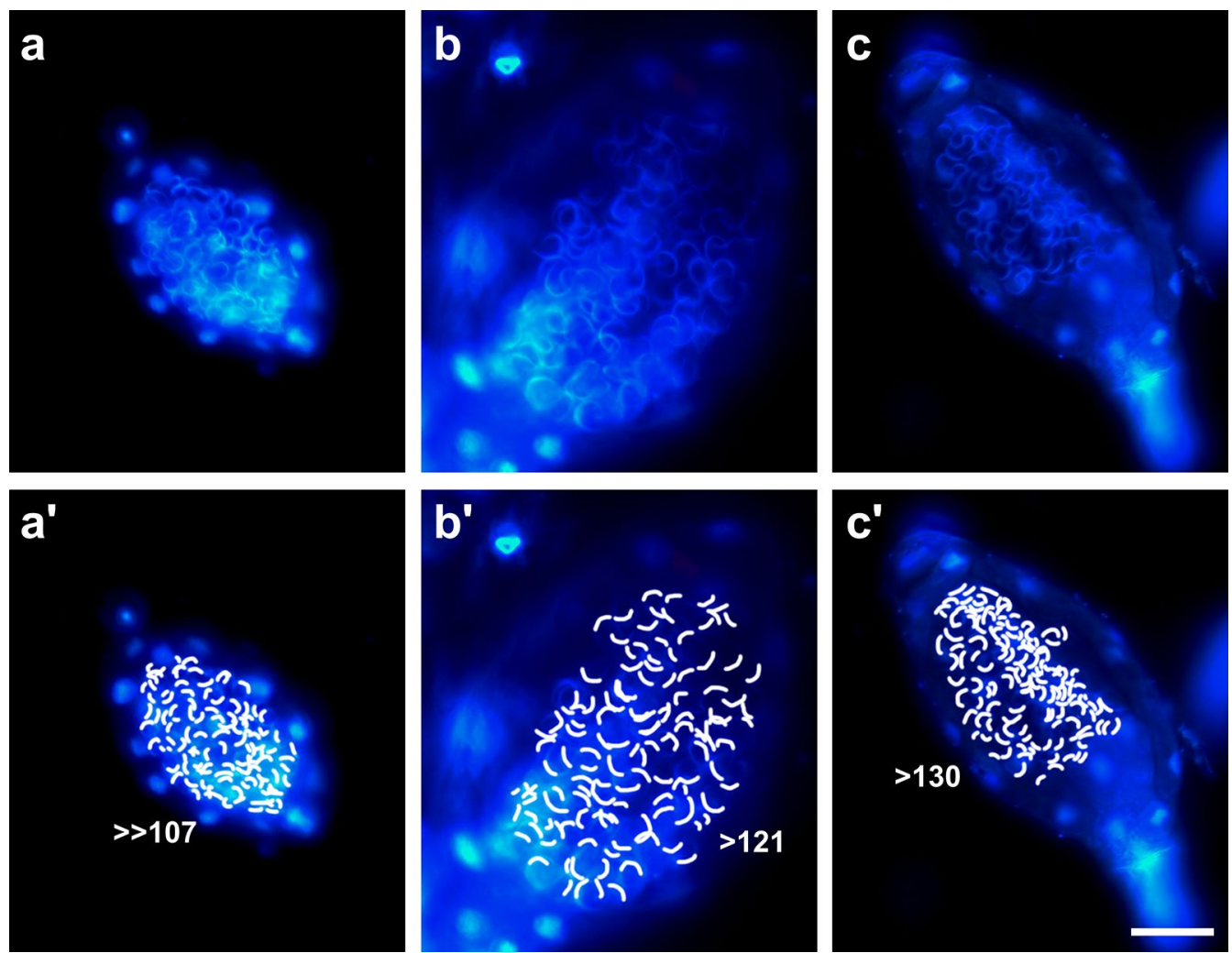

Fig. 3 Approximation of sperm number per antheridium. Fixed samples of three antheridia $(\mathbf{a}, \mathbf{b}, \mathbf{c})$ with each visible spermatozoid indicated $\left(\mathbf{a}^{\prime}, \mathbf{b}^{\prime}\right.$, c'). DNA was stained with DAPI. Panel b has been reused from Fig. 2. Scale bar $50 \mu \mathrm{m}$

double-sided tape to the benchtop next to the dissecting microscope and leave undisturbed for $24 \mathrm{~h}$. The plates can be left attached to the benchtop for a couple of days until the analysis is completed.

- Place a drop of water on a microscope slide.

- Open the lid of the petri dish with the bottom staying attached to the benchtop. Close the lid between removing gametophores to avoid desiccation of the plants.

- Pick one gametophore at a time. Under a dissecting microscope hold a gametophore with one pair of forceps and using another pair of forceps, brush the antheridia into the water.

- Critical step Immediately place a coverslip on the sample and proceed with light microscopy. The sperms are released within a few minutes once the plants are manipulated; delays will cause the sperms to disperse in the water making it more difficult to observe them and possibly missing a chance to watch an antheridium releasing the sperms.

- Using phase contrast microscopy and the $10 \times$ or $20 \times$ objective, screen the slide for sperms.

- When the apical cell of an antheridium ruptures, the bulk of the sperm mass is rapidly discharged, followed by a slow flow of the remaining sperms.
4. Staining with propidium iodide to analyse sperm viability

Propidium iodide stains nucleic acids but does not enter intact membranes. It is therefore widely used to check for non-viable sperms [6, 23, 32, 33]. The consistency between the results obtained by phase contrast microscopy compared to the use of dyes such as propidium iodide has previously been confirmed for three moss species [23].

- Using water with $10 \mu \mathrm{g} / \mathrm{ml}$ propidium iodide follow the above protocol for the observation of live sperms.

- Upon detection of sperms utilizing phase contrast microscopy, switch to epifluorescence and observe propidium iodide fluorescence with a rhodamine filter set.

- Continue observing the sperms to determine their life span.

\section{Microscopy}

Sperms are transparent (Fig. 4) depending on the application. An increase in contrast can be achieved by staining with DAPI or by phase contrast microscopy. 


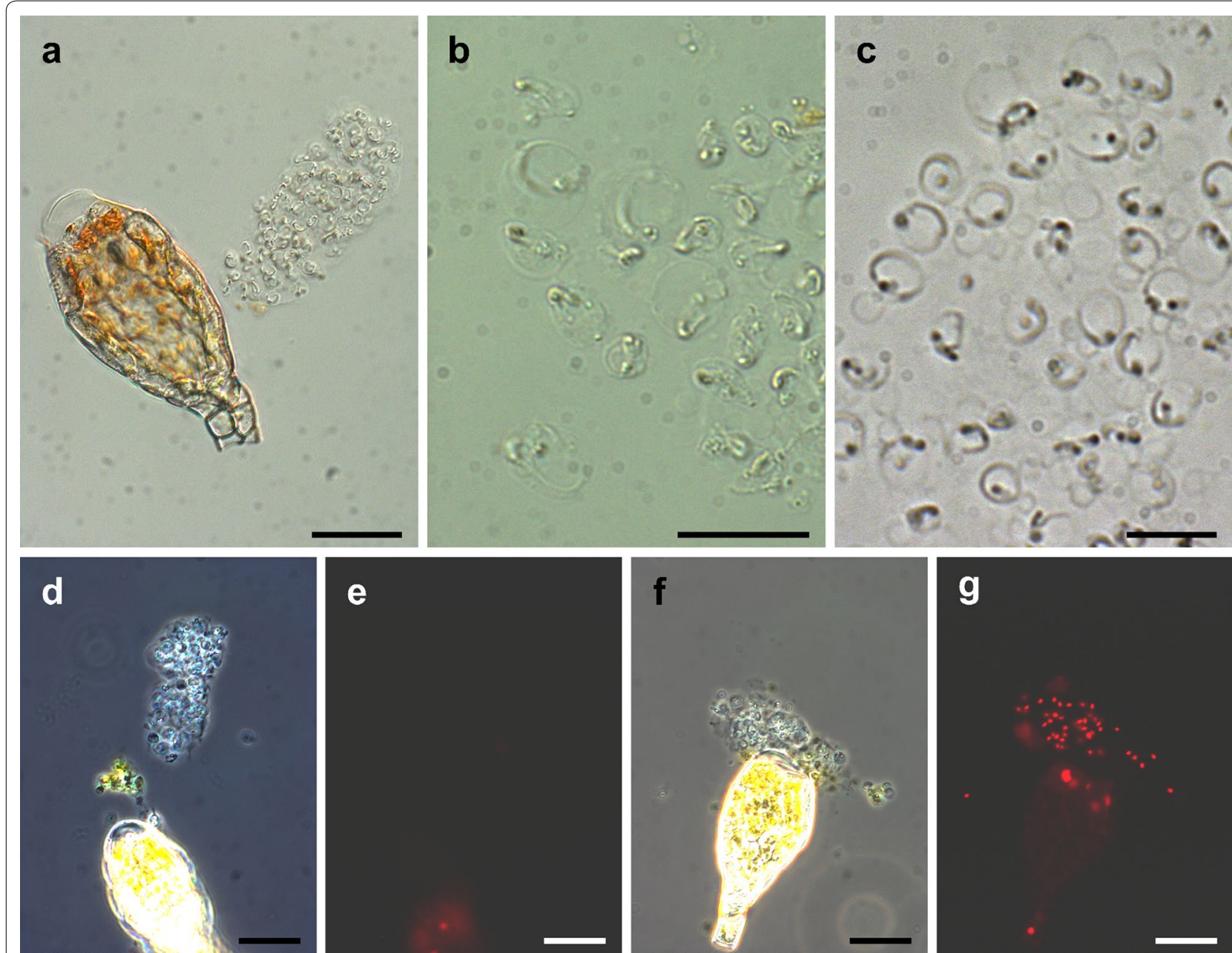

Fig. 4 Live observation and sperm viability. a Bright field image of a sperm mass released from an antheridium, note that the tip cell of the antheridium is free of content due to cell rupture. b Bright field image of sperms. c Phase contrast image of sperms. Viable (d, e) and non-viable (f, g) sperms. Phase contrast (left) and fluorescence (right) images of the same view, non-viable sperms are stained with propidium iodide. Scale bars $50 \mu \mathrm{m}$ in $\mathrm{a} ; 10 \mu \mathrm{m}$ in $\mathbf{b}, \mathbf{c} ; 20 \mu \mathrm{m}$ in $\mathbf{d}-\mathbf{g}$

\section{Methods}

Images were acquired with an Mrc5 CCD camera (Zeiss, Oberkochen, Germany) at an Olympus SZX-7 dissecting microscope (Tokyo, Japan) (Fig. 1a) and an Axioplan 2 (Zeiss). The images displayed in Figs. 2a-f, 3, 4a, d-g were acquired with a $40 \times$ objective (numerical aperture 0.75, air), the images displayed in Figs. $2 \mathrm{~g}, \mathrm{~h}, 4 \mathrm{~b}$, c were acquired with a $100 \times$ objective (numerical aperture 1.30, oil). Immersion oil ZEISS $518 \mathrm{~N}$ (ne $=1.518$, Zeiss) was used. Epifluorescence microscopy of DAPI or propidium iodide stained samples was performed with a BP 365 FT 395 LP 397 and a BP 546 FT 580 LP 590 filter set, respectively.

Figure 1a is composed of two images of different focal planes utilizing CombineZ (http://www.hadleyweb.pwp. blueyonder.co.uk/).

\section{Results and discussion}

This article describes the methodology to analyse $P$. patens sperms starting with the suitable conditions to induce development of the male gametangia, the selection of appropriate samples for analysis, and easy to follow protocols for the observation of fixed and live cells with a light microscope. Presence of antheridia can be assessed in a dissecting microscope with the plants in a sealed petri dish, allowing continuing axenic cultivation until antheridia are present.

The procedure to observe bryophyte sperms described in literature is to submerge the antheridia in water, wait for the release of white sperm masses, collect these with a micropipette, and observe them in a microscope counting chamber $[23,24,26]$. Attempting to use these methods with $P$. patens, we failed to observe the release 
of white sperm masses under a dissecting microscope (shown e.g. in [24]) or motile spermatozoids. Paolillo [21] describes observing the release of sperms of Funaria hygrometrica (like P. patens a Funariaceae species) as "delicate and tedious" in comparison to e.g. Atrichum undulatum, Polytrichum juniperinum, and Mnium affine. Paolillo attributes this to the small size of $F$. hygrometrica antheridia, a low proportion of ripe antheridia and a particularly brief interval between disturbance by preparing the antheridia and opening of the antheridia. Furthermore, the mechanism for the expulsion of sperms varies between species: while in A. undulatum, P. juniperinum, and $M$. affine there is a fluid-filled space in the base of the antheridial chamber below the sperm mass supporting expulsion, this is absent in F. hygrometrica [21]. P. patens antheridia do not have such a fluid-filled space either, indicating a mechanism similar to F. hygrometrica. Therefore we hypothesized that moving the plants from the climate cabinet to the microscope already causes sufficient disturbance to release the antheridia into the water film on the gametophores. Indeed, once we started to leave the plates undisturbed for $24 \mathrm{~h}$, picked one gametophore at a time, and speedily proceeded to light microscopy, we observed released motile sperms (see supplemental videos in [6]).

Bryophyte antheridia are described as containing thousands of spermatozoids [34]. The number of sperms is much lower in the $P$. patens strain used here, namely about 150-200 sperm cells per antheridium (Fig. 3). So a likely explanation for not seeing released sperm masses under the dissecting microscope is the low number of spermatozoids per antheridium and therefore the small size of the sperm masses as well as the fast release and the subsequent spread of the sperms.

Another factor is the age of the antheridia: we only observed viable sperms when looking at clusters of young antheridia. Older clusters have some closed antheridia as well; however, their spermatozoids were usually non-viable. These antheridia actually released sperms when we had not left the petri dishes undisturbed. Based on this fact we speculate that under laboratory conditions without external disturbance of the plants, a proportion of the antheridia will die without having released the sperms. In these dead antheridia the pressure in the internal space would not be maintained due to the lack of active transport of water [22] and the sperms will be squeezed out of the antheridium by the weight of the coverslip.

Overall, we suggest that the methodology developed for the analysis of other bryophyte spermatozoids is not suited for $P$. patens, requiring specific protocols as described here.

Utilizing propidium iodide to identify non-viable sperms allows a distinction between mutants affected in motility or viability, respectively. Various Chlamydomonas reinhardtii mutants affected in flagellar motility have been described [35], the fern Ceratopteris richardii sleepy sperm mutant develops slow and nonmotile sperms [36]. The widely used $P$. patens Gransden 2004 strain, which was also used for genome sequencing [37], has been reported to possess reduced male fertility in comparison to the Villersexel ecotypes which may be due to a reduced number of motile sperms in Gransden 2004 plants [38]. Further research involving the various $P$. patens ecotypes is required to elucidate whether this is a variation between different ecotypes or that arose during laboratory cultivation. In previous studies the Gransden 2004 laboratory strain and the Villersexel K3 ecotype exhibited the largest amount of genetic variations between all European ecotypes tested but were able to fertilize each other $[39,40]$.

The spermatozoids of bryophytes are different from human sperms in morphology and development: mammalian sperms are monoflagellated with a spherical head containing the nucleus, the germ line is separated early during embryogenesis, and they are a direct product from meiosis. In contrast, the biflagellated bryophyte sperms have a coiled nucleus and develop from plant cells, requiring massive modifications such as the removal of the cell wall and the de novo establishment of microtubule organizing centres [41], and meiosis (occurring in the spore mother cell) is separated from spermatogenesis. Nevertheless, the ciliary structure was present in the last eukaryotic common ancestor [42], e.g. the $9+2$ arrangement of the microtubule axoneme was first observed in moss spermatozoid flagella [43]. Targeted deletion of $P$. patens homologs of flagellar proteins will help to elucidate conserved functions of such proteins, with the advantage that in contrast to metazoans, such mutants can be easily vegetatively propagated and maintained as such a defect is specific to the flagellated sperms but does not affect regular plant cells.

The analysis of fixed cells provides a fast method for the general assessment of sperms, including developmental stages still within the antheridium (Fig. 2). Due to their small size, $P$. patens antheridia can be easily fixed and observed as whole-mount samples without the requirement for microscopic sections e.g. performed of M. polymorpha antheridia [25]. In particular the attachment of released spermatozoids to polylysine-coated slides considerably reduces the necessary preparation time for the observation of sperms.

\section{Conclusions}

This is the first methodology article for the observation of P. patens sperms. Due to species-specific peculiarities of the antheridia, attempts to follow protocols used in other 
species were futile. The use of whole-mount samples and a standard laboratory microscope allows the fast analysis of samples without the requirement for expert knowledge of techniques that are time-consuming or not established in every laboratory. The protocol for observing fixed released spermatozoids attached to polylysine-coated slides is fast and simple and excellently suited for use in teaching. We expect these easy-to-follow protocols to aid in the establishment of the analysis of $P$. patens sperms and increase research efforts.

\section{Authors' contributions}

RR initiated the project. NAH designed and carried out the experiments. NAH and RR discussed the results and wrote the manuscript. Both authors read and approved the final manuscript.

\section{Author details}

${ }_{1}$ Plant Biotechnology, Faculty of Biology, University of Freiburg, Schaenzlestr. 1,79104 Freiburg, Germany. ${ }^{2}$ BIOSS - Centre for Biological Signalling Studies, University of Freiburg, Schaenzlestr. 18, 79104 Freiburg, Germany.

\section{Acknowledgements}

We thank Anne Katrin Prowse for proof reading of the manuscript. The article processing charge was funded by the German Research Foundation (DFG) and the Albert Ludwigs University Freiburg in the funding programme Open Access Publishing.

\section{Availability of data and materials}

All data generated or analysed during this study are included in this published article. This work was performed with the P. patens Gransden accession [44]. Specifically, it was generated by consecutive self-fertilization of descendants of the Gransden 2004 strain used for genome sequencing [37]. The Gransden 2004 strain (accession number 40001), the Villersexel ecotypes (accession numbers 40012 and 40013) as well as several further P. patens ecotypes are available through the International Moss Stock Center IMSC (http://www. moss-stock-center.org/).

\section{Competing interests}

The authors declare that they have no competing interests.

\section{Funding}

This study was supported by the Excellence Initiative of the German Federal and State Governments (EXC 294).

\section{Publisher's Note}

Springer Nature remains neutral with regard to jurisdictional claims in published maps and institutional affiliations.

Received: 1 September 2016 Accepted: 2 May 2017

Published online: 10 May 2017

\section{References}

1. Joint Genome Institute. http://jgi.doe.gov/our-science/ science-programs/plant-genomics/plant-flagship-genomes/.

2. Plavskin Y, Nagashima A, Perroud P-F, Hasebe M, Quatrano RS, Atwal GS, Timmermans MCP. Ancient trans-acting siRNAs confer robustness and sensitivity onto the auxin response. Dev Cell. 2016;36:276-89.

3. Tam THY, Catarino B, Dolan L. Conserved regulatory mechanism controls the development of cells with rooting functions in land plants. Proc Natl Acad Sci USA. 2015;112:E3959-68.

4. Bennett TA, Liu MM, Aoyama T, Bierfreund NM, Braun M, Coudert Y, Dennis RJ, O'Connor D, Wang XY, White CD, Decker EL, Reski R, Harrison CJ. Plasma membrane-targeted PIN proteins drive shoot development in a moss. Curr Biol. 2014;24:2776-85.
5. Sakakibara K, Ando S, Yip HK, Tamada Y, Hiwatashi Y, Murata T, Deguchi $\mathrm{H}$, Hasebe M, Bowman JL. KNOX2 genes regulate the haploid-to-diploid morphological transition in land plants. Science. 2013;339:1067-70.

6. Horst NA, Katz A, Pereman I, Decker EL, Ohad N, Reski R. A single homeobox gene triggers phase transition, embryogenesis and asexual reproduction. Nat Plants. 2016;2:15209.

7. Chater CC, Caine RS, Tomek M, Wallace S, Kamisugi Y, Cuming AC, Lang D, MacAlister CA, Casson S, Bergmann DC, Decker EL, Frank W, Gray JE, Fleming A, Reski R, Beerling DJ. Origin and function of stomata in the moss Physcomitrella patens. Nat Plants. 2016;2:16179.

8. Stevenson SR, Kamisugi Y, Trinh CH, Schmutz J, Jenkins JW, Grimwood J, Muchero W, Tuskan GA, Rensing SA, Lang D, Reski R, Melkonian M, Rothfels CJ, Li F-W, Larsson A, Wong GK-S, Edwards TA, Cuming AC. Genetic analysis of Physcomitrella patens identifies ABSCISIC ACID NON-RESPONSIVE (ANR), a regulator of ABA responses unique to basal land plants and required for desiccation tolerance. Plant Cell. 2016;28:1310-27.

9. Reski R. Development, genetics and molecular biology of mosses. Bot Acta. 1998;111:1-15.

10. Sakakibara K, Nishiyama T, Deguchi H, Hasebe M. Class 1 KNOX genes are not involved in shoot development in the moss Physcomitrella patens but do function in sporophyte development. Evol Dev. 2008;10:555-66.

11. Harrison CJ, Roeder AHK, Meyerowitz EM, Langdale JA. Local cues and asymmetric cell divisions underpin body plan transitions in the moss Physcomitrella patens. Curr Biol. 2009;19:461-71.

12. Landberg K, Pederson ERA, Viaene T, Bozorg B, Friml J, Jonsson H, Thelander M, Sundberg E. The moss Physcomitrella patens reproductive organ development is highly organized, affected by the two SHI/STY genes and by the level of active auxin in the SHI/STY expression domain. Plant Physiol. 2013;162:1406-19.

13. Ortiz-Ramírez C, Hernandez-Coronado M, Thamm A, Catarino B, Wang M, Dolan L, Feijó JA, Becker JD. A transcriptome atlas of Physcomitrella patens provides insights into the evolution and development of land plants. Mol Plant. 2016;9:205-20.

14. Thuret G. Recherches sur les zoospores des algues et les anthéridies des cryptogames. Ann Sci Nat Sér. 1851;16:5-39.

15. Wilson M. Spermatogenesis in the Bryophyta. Ann Bot. 1911;25:415-57.

16. Bernhard DL, Renzaglia KS. Spermiogenesis in the moss Aulacomnium palustre. Bryologist. 1995;98:52-70.

17. Duckett JG, Carothers ZB, Moser JW. Ultrastructural studies of spermatogenesis in the Anthocerotales. III. Gamete morphogenesis: from spermatogenous cell through midstage spermatid. Gamete Res. 1980;3:149-67.

18. Carothers ZB, Rushing AE. Comparative morphology of the bryophyte blepharoplast. Adv Bryol. 1988;3:95-134.

19. Paolillo DJ. The release of sperms from the antheridia of Polytrichum juniperinum Hedw. New Phytol. 1975;74:287-93.

20. Paolillo DJ. On the release of sperms in Atrichum. Am J Bot. 1977;64:81-5.

21. Paolillo DJ. Release of Sperms in Funaria hygrometrica. Bryologist. 1977;80:619.

22. Paolillo DJ. The swimming sperms of land plants. Bioscience. 1981:31:367-73.

23. Shortlidge EE, Rosenstiel TN, Eppley SM. Tolerance to environmental desiccation in moss sperm. New Phytol. 2012;194:741-50.

24. Stark LR, McLetchie DN, Greenwood JL, Eppley SM. Moss antheridia are desiccation tolerant: rehydration dynamics influence sperm release in Bryum argenteum. Am J Bot. 2016;103:856-64.

25. Higo A, Niwa M, Yamato KT, Yamada L, Sawada H, Sakamoto T, Kurata T, Shirakawa M, Endo M, Shigenobu S, Yamaguchi K, Ishizaki K, Nishihama $\mathrm{R}$, Kohchi T, Araki T. Transcriptional framework of male gametogenesis in the liverwort Marchantia polymorpha L. Plant Cell Physiol. 2016:57:325-38.

26. Furuichi T, Matsuura K. Kinetic analysis on the motility of liverwort sperms using a microscopic computer-assisted sperm analyzing system. Environ Control Biol. 2016:54:45-9.

27. Hohe A, Rensing SA, Mildner M, Lang D, Reski R. Day length and temperature strongly influence sexual reproduction and expression of a novel MADS-box gene in the moss Physcomitrella patens. Plant Biol. 2002:4:595-602.

28. Reski R, Abel WO. Induction of budding on chloronemata and caulonemata of the moss, Physcomitrella patens, using isopentenyladenine. Planta. 1985;165:354-8. 
29. Egener T, Granado J, Guitton M-C, Hohe A, Holtorf H, Lucht JM, Rensing S, Schlink K, Schulte J, Schween G, Zimmermann S, Duwenig E, Rak $B$, Reski R. High frequency of phenotypic deviations in Physcomitrella patens plants transformed with a gene-disruption library. BMC Plant Biol. 2002;2:6.

30. Decker EL, Wiedemann G, Reski R. Gene targeting for precision glycoengineering: production of biopharmaceuticals devoid of plant-typical glycosylation in moss bioreactors. In: Castilho A, editor. Methods in Molecular Biology. New York: Springer; 2015. p. 213-24.

31. Frank W, Decker EL, Reski R. Molecular tools to study Physcomitrella patens. Plant Biol. 2005:7:220-7.

32. Garner DL, Johnson LA. Viability assessment of mammalian sperm using SYBR-14 and propidium iodide. Biol Reprod. 1995;53:276-84.

33. Zhang G, Campenot MK, McGann LE, Cass DD. Flow cytometric characteristics of sperm cells isolated from pollen of Zea mays L. Plant Physiol. 1992;99:54-9.

34. Garbary DJ, Renzaglia KS, Duckett JG. The phylogeny of land plants: a cladistic analysis based on male gametogenesis. Plant Syst Evol. 1994;188:237-69.

35. Fujita S, Matsuo T, Ishiura M, Kikkawa M. High-throughput phenotyping of Chlamydomonas swimming mutants based on nanoscale video analysis. Biophys J. 2014;107:336-45.

36. Renzaglia KS, Wood KD, Rupp G, Hickok LG. Characterization of the sleepy sperm mutant in the fern Ceratopteris richardii : a new model for the study of axonemal function. Can J Bot. 2004;82:1602-17.
37. Rensing SA, Lang D, Zimmer AD, Terry A, Salamov A, Shapiro H, et al. The Physcomitrella genome reveals evolutionary insights into the conquest of land by plants. Science. 2008;319:64-9.

38. Perroud P-F, Cove DJ, Quatrano RS, McDaniel SF. An experimental method to facilitate the identification of hybrid sporophytes in the moss Physcomitrella patens using fluorescent tagged lines. New Phytol. 2011;191:301-6.

39. von Stackelberg M, Rensing SA, Reski R. Identification of genic moss SSR markers and a comparative analysis of twenty-four algal and plant gene indices reveal species-specific rather than group-specific characteristics of microsatellites. BMC Plant Biol. 2006;6:9.

40. Kamisugi Y, Cuming AC, Cove DJ. Parameters determining the efficiency of gene targeting in the moss Physcomitrella patens. Nucleic Acids Res. 2005;33:e173.

41. Vaughn KC, Harper JDI. Microtubule-organizing centers and nucleating sites in land plants. In: Jeon KW, editor. International review of cytology. Amsterdam: Elsevier; 1998. p. 75-149.

42. Hodges ME, Wickstead B, Gull K, Langdale JA. Conservation of ciliary proteins in plants with no cilia. BMC Plant Biol. 2011;11:185.

43. Manton I, Clarke B. An electron microscope study of the spermatozoid of Sphagnum. J Exp Bot. 1952;3:265-75.

44. Ashton NW, Cove DJ. Isolation and preliminary characterization of auxotrophic and analog resistant mutants of moss, Physcomitrella patens. Mol Gen Genet. 1977;154:87-95.

\section{Submit your next manuscript to BioMed Central and we will help you at every step:}

- We accept pre-submission inquiries

- Our selector tool helps you to find the most relevant journal

- We provide round the clock customer support

- Convenient online submission

- Thorough peer review

- Inclusion in PubMed and all major indexing services

- Maximum visibility for your research

Submit your manuscript at www.biomedcentral.com/submit 